\title{
Self-directed learning in later life: motives and learning competences of retired teachers
}

\section{Salomèja Šatienè}

\begin{abstract}
The purpose of this article is to explore self-directed learning of retired teachers looking into their perceptions of motivation and learning competences. The qualitative research included semi-structured face-to-face interviews with eight retired teachers engaged in their self-directed learning pursuits. The empirical data allows to construct a description of the self-directed learning among retired teachers in a small rural community in Lithuania. Each theme drawn from the analysis of empirical data reflects a range of elements in the construction of subjective learning trajectories based on the participants' experiences perceived as self-directed learning. The learning behaviours of the retired teachers provide support for continuity theory.
\end{abstract}

Keywords: self-directed learning, later life, retired teachers. 


\title{
Samostatně řízené učení ve vyšším věku: motivy a kompetence $\mathrm{k}$ učení $\mathrm{u}$ učitelů $\mathrm{v}$ důchodu
}

\begin{abstract}
Abstrakt
Cílem tohoto článku je zkoumání samostatně řízeného učení učitelů v dưchodu se zaměřením na vnímání motivace a kompetencí k učení. Kvalitativní výzkum zahrnoval polostrukturované osobní rozhovory s osmi učiteli v důchodu, které se zabývaly jejich vlastními vzdělávacími aktivitami. Empirické údaje umožňují konstruovat popis samostatně zaměřeného učení mezi učiteli v důchodu v malé venkovské komunitě v Litvě. Každé téma vycházející z analýzy empirických dat odráží řadu prvků v konstrukci subjektivních učebních trajektorií založených na zkušenostech účastníků, které jsou vnímány jako samostatné učení. Učitelské chování učitelů v důchodu poskytuje podporu teorii kontinuity.
\end{abstract}

Klíčová slova: samostatné učení, pozdější život, učitelé v důchodu.

\section{Introduction}

In the last decades, learner self-directedness has been given considerable attention in adult education research, due to the recognition of the increased importance of the learner ability to learn independently in the fast changing learning environments. With the recognition that most older adult learning is through non-formal and informal means (Merriam \& Bierema, 2014), there arises a need to study self-directed learning in informal learning environments taking into consideration different social and cultural contexts (Jarvis, 2001, Russel, 2011, Hiemstra and Brockett, 2012, Findsen, 2016). The level of education, vocational biographies, prior learning experiences and subjective perceptions of ageing have been identified as factors influencing learning abilities and disposition (Schmidt, 2013). However, until recently, there has been little empiric research into self-directed learning in later life related to a diversity of socio-economic and cultural backgrounds of older learners.

Self-directed learning as a modern learning paradigm has been subject to broad interpretation. As pointed out by Owen (2002), self-direction in adult learning has been referred to as self-teaching, self-planned learning, independent adult learning, selfdirected learning, and self-initiated learning. In this study we approach the concept of self-directed learning as autodidactic self-learning, i.e. the individual non-institutional pursuit of learning opportunities (Candy, 1991). In this view self-directed learning is defined as a form of informal learning, which is both intentional and conscious (Schugurensky, 2000, p. 4). The extent to which adult learners exhibit autonomous behaviour is 
influenced by the learner's commitment to learning and sense of personal competence as a learner (Merriam, Caffarella, 1999). The learner personality dimension in self-directed learning construct is related to learner qualities including agency, autonomy and self-efficacy. Life experience, motivation, previous education, self-concept (Hiemstra and Brocket, 2012), learning strategies, the ability to reflect on and evaluate one's own learning (Schmidt, 2013) have been shown to play an important role in self-directed learning of older adults.

Teacher self-directedness and meta-learning competence as major characteristics of teacher learning based on professional development abilities and managing one's own learning process have been widely emphasized in academic literature (James and McCormic, 2009, Hoekstra, Korthagen, 2011, Jurasaite-Harbison and Rex, 2010, Kvederaite, 2009, Postholm, 2012, Pyhalto et al., 2015). Juodaityte and Kvederaite (2010), having conducted a research on teachers' self-directed learning competences in Lithuania, identified teachers' self-directed learning abilities and competencies including the abilities to identify learning needs, learn in social interaction processes, take responsibility for learning, plan learning in an autonomous manner and the constant learning competency, "which discloses motivation of teachers' continuous improvement and learning“(p. 92).

\section{Research}

The research focus of the present study on self-directedness of teachers as later-life learners is predicated on a view that retired teachers make up a group of older adult learners, who due to their previous occupational background possess specialist metalearning competence (Kvederaite, 2009) and expert ability to reflect on, critically evaluate and articulate learning experiences (Jurasaite-Harbison, Rex, 2013). The purpose of this article is to explore self-directed learning of retired teachers looking into their perceptions of motivation and learning competences. The following questions are raised: What motivates the retired teachers to engage in self-directed learning? How the teaching background impacts their learning competences? Exploring the interrelationship between three constructs - self-directed learning, later life learning and the learner identity, the present study will address the research issue from the theoretical perspectives of the continuity theory of ageing and the social constructivist theory. The continuity theory is a major social theory of ageing concerning patterns of activity in later life, which maintains that continuity is a primary adaptive strategy for dealing with aging related changes (Atchley, 1989). Adults adapt to aging by maintaining patterns of thinking, activities and relationships, which are based on their past experiences and "provide most people with robust resources for coping with changing circumstances" (Atchley, 2006, p. 28). Constructivism has been proposed as a theoretical framework for 
the study of self-direction in learning as related to ageing by some leading theorists in the field of adult learning (Candy, 1989, Illeris, 2003) emphasizing the older learner's active role and the socially constructed nature of the self in later life. Social constructivist theory (Berger, Luckmann, 1999) emphasizes the importance of previous experience in construction of knowledge which is determined by the individual's cognitive behaviour and interaction with the environment. In this perspective learning in later life is viewed as construction of meaning by older people with respect to their perceptions of themselves as learners and the learning process.

\section{Method}

A phenomenological methodology was chosen to gain in-depth insights into later life learning by listening to and interpreting the participants' lived experiences. We conducted qualitative research which included semi-structured face-to-face interviews with eight retired teachers engaged in their self-directed learning pursuits. The interviews were carried out in November to December 2016 with a purposive sample of 8 male and female retired teachers aged between 65 and 82, having been retired for 6 months to 15 years, living in a small town in a rural area in Lithuania. The sample was selected based on the research aim, applying the target selection approach when individuals are selected purposefully (Kvale, 1996) without aiming at representativeness of the sample according to conventional empirical research procedures. The interviews focused on the participants' perceptions of their learning motives, needs and experiences with the aim to explore learning of the target group and examine the dynamics between the participants' professional background and their attitudes and learning patterns. The researcher based her analysis and interpretation of the findings on the literature review in the field and her understanding of the socio-cultural context. The participants were provided reference codes to ensure anonymity.

\section{Results}

Based on the analysis of the interview data, there were two principal themes derived from the participants' perceptions of their self-directed learning in later life as related to the participants' professional background: motivation factors and the learning competences based on personal resources. 


\subsection{Motivation for later life learning}

Examination of the participants' perceptions of the need for and meaning of their later life learning revealed the following elements related to the motivation dimension: realizing the need for personal growth through one's lifetime; preserving the teacher identity; making productive contributions to the environment based on professional skills; maintaining life-long interests.

\section{Pursuing personal growth}

All the participants perceived learning in later life as inherent part of their life-long engagement in learning and pursuit of personal growth recognizing the existential meaning of learning in later life. As Mrs. B put it: "The more I read and look into different things, the more I realize that there is still so much I don't know and so much to learn, otherwise our existence will be very poor, I mean that of retired people". Mr. D believes that "retirement was not like crossing a line - for me it was continuation, I did not feel any transition or a new phase in my interests. I have always pursued knowledge of the world, and it has always been good talking to people about one thing or another... I read those things now and then to refresh my thoughts". The other corroborating statements included: "you get that self-confidence and the desire to learn more", "the need for knowledge for a retired person is as strong as the need for warmth or food", "there is no single day without me learning something".

\section{Preserving the teacher identity}

All the participants spoke of their teaching background with reference to their current activities, their role in the community and their view of themselves as lifelong learners. They spoke of "the inherent teacher responsibility, which becomes part of you", "which can be expressed in the word 'must', encouraging other people to take part in [learning] activities, and feeling good when "you see some mature men, your former pupils, participating in educational community events", "wanting things to be done properly and opposing other people's careless attitudes", and "the character remaining that of a teacher, though you have retired". Recognizing the fact that living in a small town, teachers have to live up to the expectations of the community and maintain the image of a sophisticated individual, the participants associated the retirement with loss of their previous status in community, as Mrs. B explicitly described: "Sometimes it feels as if we [retired teachers] are 'written off', as if there is a seal placed on you, and you feel unworthy of attention". However, they admit, that when there are cultural or educational events organized, the teachers enjoy being invited and readily attend those events "as sophisticated audience, who will be able to ask some 'intelligent questions', share their experience on the subject or provide some insights", which they see as an indication that retired teachers are still acknowledged for their expertise. This attitude encourages 
the retired teachers to learn so that "to be able to take part in discussions", "keep up with the rapid pace of life change", "maintain your interest in new developments in politics and everything", "so that they don't say'you don't know, you are too old".'

\section{Making productive contributions to the environment}

Most respondents pointed out the realized need for being useful and needed, and contributing to their environment including both family and a wider community. Mrs. $B$, a retired teacher of the Lithuanian language and literature, articulated it explicitly:"I somehow think it's in my nature... as it's about time for me to start thinking of leaving this world as my health has deteriorated... so I start asking myself "What do I have and what will I leave behind?" She has initiated collection of materials to write a history of the village school and involved some other retired teachers in this job. Mrs.A reported her reason: "When I was affected by cancer for the second time, I made a promise to myself and God to start a prayer group in our town after recovery. And so I did. We've had it for three years now". The family reasons for some participants were related to looking after elderly or ill family members. As Mrs. C put it: "I felt as if it was a shift from my teaching job to that of nursing. Now I can give advice to other people who are nursing their family members". However, some of the participants admitted, that they would never do community things on their own initiative without being asked for their contribution: "I can write an article [about school issues], if somebody asks and I do when they need one, but otherwise - no" (Mr. D).

\section{Maintaining lifelong interests}

All the respondents talked about continuing their interests, which they had "most of their lives", the difference being that they enjoy having more time now for their pursuits or their interests have acquired new directions. All of them have been collecting books all their lives and although this process has slowed down with retirement, most of them now have rich collections in their private libraries and enjoy having more time for reading which was limited through their careers. All the participants talked about the relevance of the subject knowledge they accumulated through the years of professional career, and their interest in educational issues. As Mrs. G explained:"I haven't withdrawn into myself, there are still my skills, my habits, and I am interested in what is going on at our national school". Although most participants pointed out that generally there is no direct need for the development of their subject knowledge in retirement, they reported a number of reasons to continue practicing their specialist knowledge and skills. We divided the reasons for maintaining subject-related interests into three categories: family-related, occupation-related, leisure-related and "nostalgic" reasons. Familyrelated reasons make the major group and include helping grandchildren or younger relatives with their learning at school, discussing some subject-related issues with other family members, giving advice to younger family members in a teaching profession. 
For example, Mrs. C, a former school deputy principal, gives advice to her niece, a social educator:"she calls me to ask for advice about dealing with disruptive behaviour - she draws on my expertise". Mr. E, a retired teacher of history and former school principle, can share his knowledge discussing different issues of history and politics with his son or friends, give advice to his daughter, a teacher, or answer his nine-year-old grandson's history-related questions. Mrs. A, a teacher of English, named a revived need for English to talk to her son's English speaking girlfriend: "When I finished my career, I thought I would never need knowledge of English again, but now life itself demands to brush it up". Occupation related reasons are linked to finding new areas of productive activity, like Mrs. H, a teacher of English, said: "I did a computer literacy course when I had an opportunity, I thought I could try and find a translation job online [using the skills of the English language]". Mrs. B prepared materials for the museum website, wrote and edited the texts using her skills as a linguist. Leisure related reasons are linked to attending events related to their subject or reading professional literature. Mr. D, a retired teacher of Lithuanian language and literature, still reads contemporary Lithuanian literature related publications and attends book presentations by contemporary writers, familiarizing himself with the reviews on the subject before attending the event. Mrs. $B$, a teacher of Lithuanian language and literature has been reading one journal since she started her teaching career: "it still appeals to me, and the Lithuanian literature is still important to me". We gave the term of "nostalgic" to the category of reasons due to the language the respondents used when speaking about feeling "a little ashamed" for reading publications about teaching methods designed only for practicing teachers: "I know I will not need that knowledge, but it's still interesting, and I can't give it up yet", "I missed those articles, and the knowledge", "I subscribed it for two years to my home so that not to look strange if I kept coming to the library to read it".

\subsection{Self-directed learning competences}

Examination of the participants' perceptions of the nature and patterns of their later life allowed identifying some elements of the learning competences as personal capacities that the participants draw on in their learning: self-efficacy beliefs, meta-learning competence, and experiential learning strategies.

\section{Drawing on self-efficacy beliefs}

The respondents reported a high level of efficacy regarding self-direction in learning. The corroborating statements included: "If I see a need for learning, I engage in it and I manage to achieve the results", "early in my life I got the idea that I had to achieve everything by myself, with no support", "we have acquired enough knowledge ourselves through our lives to deal with our problems", "I am thinking a lot and trying to find my way", "I can manage all things with technologies as much as I need", "I have always been 
self-confident:. Mrs. A's report was an example of self-efficacy manifestation:"I engage in learning those things that I need - I just take to that and learn. I mean things which I will be able to use. I wanted to see the photographs from our trip to the Shrine of Virgin Mary uploaded on Facebook by our parish priest, so I created a personal account and profile on Facebook myself; and I have also learnt to make medical appointments online by myself".

\section{Relying on meta-learning competence}

All the participants reported a high level of reliance on their professional expertise in their learning. The meta-learning competence was manifested in the ability to set the learning goals for learning new skills (knitting, embroidery, learning a language, creating a Facebook profile, wood or metal work, photography etc.); engaging in a new activity (collecting local ethnographic and historical materials, setting up a prayer group, nursing of sick family members etc.); implementing the learning projects through identification of resources ("The Internet, television and newspapers, and the library are the main sources to get sufficient information"); choice of strategies ("I learnt to make embroidery pictures on my own - you just read it in the book, try and learn", "I know I can learn [English] independently, as there are plenty of resources on the Internet, and I have a dictionary at hand... you also need an organized learning environment to practice the language, which makes a difference", "first I attended a basic course [about computer skills] and when you have learnt the fundamentals, you can learn on your own"; "we went to watch another prayer group, however, we did not adopt their mode, but developed our own way"; "I do my research following my own understanding and insight"; "I read about other people's experience, and I adopt some ideas"; "I ask my friends who are proficient in that skill"; "I'm learning it now from a photography manual, and also ask my former pupil, a professional photographer, for some advice") and evaluating the outcomes ("I consider myself a small-scale beginner researcher now"; "I am so proud of myself that I managed to create my Facebook account on my own").

\section{Maintaining experiential learning strategies}

When the participants were asked to compare their current learning activities, modes and ways of learning to the way they engaged in professional development and personal growth before retirement, most argued that they continued to deal with their tasks in the way they had been doing for years, however, taking into account the needs and limitations of age-related change. Mr. E made a connection between his present practical approach to learning and professional development in pre-retirement: "I always looked for practical knowledge which I could apply in my teaching and school management, and most benefited from those training courses conducted by experts with years of experience in their fields". All the participants explicitly expressed a strong preference for learning through practice - through doing: "you develop those skills 
through years", "one must learn the way of coping by themselves - if I just read some advice, I soon forget it", "you just start doing it, keep trying and you manage somehow". The ideas reported by the participants included experimenting ("I love experimenting with plants and flowers, though I never read about gardening - I just try to grow the new kinds in my way"), openness to new experience ("I always try new things in handicraft or cooking", "keep trying new recipes I find in magazines or any other new things"), reliance on one's professional expertise ("I never had any specialist training for working in the museum, so I had to learn from my experience"). Mrs. C spoke about her learning to be a psychologist for her husband in his illness: "I just learnt being with him and tried to understand things myself - the way I could learn from my experience. You know you cannot burden other people with your problems".

\section{Discussion}

The method applied in this study proved useful in exploring retired teachers' perceptions of self-directed learning as an independent autodidactic process of continued engagement in personal self-development. Analysis of the research data allowed to identify the major characteristics related to the motivation for and learning competences used in self-directed learning of the research sample of retired teachers which include engaging in continuing personal development, preserving the teacher identity, making productive contributions to the environment, maintaining lifelong (and subject-related) interests, drawing on self-efficacy beliefs, relying on metacognitive competence and maintaining experiential strategies of learning. These themes were derived from the participants' perceptions of their self-directed learning in later life as related to their former occupation.

Similar to other resent research on older adults learning pursuits (Scott, 2004, Friebe and Schmidt-Hertha, 2013), the findings of the present study suggest that self-perception, identity and self-efficacy beliefs in one's abilities are of considerable importance to commitment to learning in later life. As all the participants perceived retirement from their professional careers as associated with loss of the previous status in community, engagement in learning was seen as a way "to sustain a long held identity in new circumstances" (Hodkinson, 2008). The findings suggest that perception of one's identity as a retired teacher and self-efficacy beliefs about one's abilities make a positive effect on older learners' self-direction in learning, which is congruous with Bandura's self-efficacy theory (1997). Self-reliance regarding one's learning abilities and strategies, and perception of learning contributing to dealing with arising life needs as motivating factors of engagement in later life learning has also been recognized by other studies (Schmidt, 2013, p. 98). The commitment to contributing to one's environment was demonstrated by the respondents engaging in productive activity. Productive activity 
for the retired teachers was associated with giving more importance to the role of learning and making contributions to the environment based on professional skills. The importance of productivity in older age as one of the most important forms of active engagement with life was also emphasized by Rowe and Kahn (1997), suggesting that learning is also a predictor of productive activity. Older people's motivation by "future-oriented and long-term values linked to the development and improvement of the social context in which they live" has also been pointed by Villar and Celdran (2012, p. 674).

The participants' meta-learning competences were shaped by the nature of professional development in the teaching profession and related to the perspective of teachers' informal learning through experience (Kvederaite et al., 2013). Learning to learn strategies facilitate self-directed learning and enable the participants to achieve their personal learning goals through establishing their learning needs, setting the goals, planning and carrying the activities by choosing and implementing adequate learning strategies to carry out their learning activities and evaluating the learning experiences. A strong emphasis on experiential nature of learning - learning from experience and through doing is likely to have some relationship with the perspective of teachers' informal learning through their professional activity and are in line with some previous research on teacher informal learning (Kvederaite et al., 2013) and learning of retired professionals, who as a group are able to utilize their possessed resources and are "already practiced in keeping the mind active" (Weiss, 2005).

The research findings are consistent with the continuity theory: older individuals using strategies tied to their past experiences of themselves and their social world (Archey, 2006). Examination of each respondent's perceptions of their later life learning showed a high level of internal continuity inherent in the participants' continued pursuit of personal development, preserving the sense of self and identity as related to their former teaching occupation and maintaining life-long interests. External continuity of activities was manifested through consistency of learning strategies - construction of knowledge based on the learning strategies accumulated over time through professional development experiences, but adapting to the needs of age-related change.

\section{Conclusion}

The empirical data allows to construct a description of the self-directed learning among retired teachers in a small rural community in Lithuania. Each theme drawn from the analysis of empirical data reflects a range of elements in the construction of subjective learning trajectories based on the participants' experiences perceived as self-directed learning. The learning behaviours of the retired teachers provide support for the continuity theory. The participants demonstrated continuity in preserving their self and 
a retired teacher identity, maintaining their subject-related interests, applying the metalearning competence and learning strategies of experiential learning acquired through professional development. The insights from this study may enrich the theory of selfdirected learning in later adulthood and practice of how older people can be assisted in their later life lerning. However, the small number of participants does not allow generalizing the research findings to a wider population. This study should be extended to larger samples of retired teachers in a number of both rural and urban communities in order to gain an accurate understanding of the characteristics of self-directed learning of retired teachers in a variety of learning environments. Further research is needed to explore self-directed learning patterns of other professional groups in order to identify similarities and differences that may exist among different groups of older learners related to their former occupations. Such studies will contribute to understanding the self-directed learning patterns of professionals in retirement, and help develop educational programmes tailored to the needs of older adults

\section{References}

Atchley, R. C. (1989). A continuity theory of normal aging. The Gerontologist, 29, 183-190.

Atchley, R.C. (2006). Continuity, Spiritual Growth, and Coping in Later Adulthood. Journal of Religion, Spirituality \& Aging, 18(2-3), 19-29.

Bandura, A. (1997). Self-efficacy: the exercise of control. New York: Freeman.

Berger, P., Luckmann, T. (1999). Socialinis tikroves konstravimas. Vilnius: Pradai.

Candy P.C. (1991). Self-direction for lifelong learning: a comprehensive guide to theory and practice. San Francisco: Jossey-Bass.

Candy, P.C. (1989). Constructivism and the Study of Self-direction in Adult Learning. Studies in the education of adults, 21 (2), 95-116.

Findsen, B. (2016). Guest editorial. International Journal of Lifelong Education, 35(5), 473-476.

Friebe, J. \& Schmidt-Hertha, B. (2013). Activities and Barriers to Education for Elderly People. Journal of Contemporary Educational Studies, 64(1), 10-27.

Hiemstra, R., Brockett, R.G. (2012). Reframing the Meaning of Self-Directed Learning: An Updated Model. Adult Education Research Conference. Retrieved from: http://newprairiepress.org/aerc/ 2012/papers/22

Hodkinson, P., Ford, G., Hodkinson H., Hawthorn R. (2008). Retirement as a learning process. Educational Gerontology, 34, 167-184.

Hoekstra, A. \& Korthagen, F. (2011). Teacher learning in a context of educational change: Informal learning versus systematically supported learning. Journal of Teacher Education, 62(1), 76-92.

Illeris, K. (2003). Towards a contemporary and comprehensive theory of learning. International Journal of Lifelong Education, 22(4), 396-406.

James, M., \& McCormick, R. (2009). Teachers learning how to learn. Teaching and Teacher Education, 25(7), 973-82.

Jarvis, P. (2001). Learning in Later Life. London: Kogan Page.

Juodaityte, A., Kvederaite, N. (2010). Manifestation of teachers' self-directed learning competences in the learning school. Teacher Education, 15(2), 80-94. 
Jurasaite-Harbison, E. \& Rex, L.A. (2013). Teachers as informal learners: workplace professional learning in the United States and Lithuania. Pedagogies: An International Journal, 8(1), 1-23.

Jurasaite-Harbison, E., \& Rex, L. A. (2010). School cultures as contexts for informal teacher learning. Teaching and Teacher Education, 26, 267-277.

Kvale, S. (1996). Interviews. An Introduction to Qualitative Research Interviewing. Thousand Oaks: Sage.

Kvederaite, N. (2009). Šiuolaikinés mokyklos kaip besimokančios organizacijos bruožu raška personal savivaldaus mokymosi sklaidos procesuose. Daktaro disertacija. Socialiniai mokslai, edukologija (07S). Šiaulių universitetas.

Kvederaite, N., Jasnauskaite, R., Geleziniene, R., \& Strazdiene, G. (2013). Forms of educational activities that enhance self-directed learning of adults. Problems of Education in the $21^{\text {st }}$ century, (56), 74-85.

Merriam, S. B. \& Bierema, L. L. (2014). Adult learning: Linking theory and practice. San Francisco, CA: Jossey-Bass.

Merriam, S. B. \& Caffarella, R. S. (1999). Learning in Adulthood: A Comprehensive Guide. San Francisco: Jossey Bass.

Owen, T. R. (2002). Self-directed Learning in Adulthood: A Literature Review. Retrieved from <http:// www.eric.ed.gov/contentdelivery/servlet/ERICServlet?accno=ED461050>

Postholm, B. M. (2012). Teachers' professional development: a theoretical review. Educational Research, 54(4), 405-429.

Pyhältö, K., Pietarinen, J., \& Soini, T. (2015). Teachers' professional agency and learning - from adaption to active modification in the teacher community. Teachers and Teaching, 21(7), 811-830.

Rowe, J. W., Kahn, R. L. (1997). Successful aging. Gerontologist, 37, 433-440.

Russell, H. (2011). Time and Meaning in Later Life Learning. Australian Journal of Adult Learning, 51(3), 547-565.

Schmidt-Hertha, B. (2013). Informal learning of older adults: Motives and opportunities in everyday life. Proceedings of $4^{\text {th }}$ International ESREA Conference. Learning Opportunities for older adults: forms, providers and policies. Vilnius: Mykolo Riomerio Universitetas.

Schugurensky, D. (2000). The forms of informal learning: towards a conceptualization of the field. WALL Working paper 19. Retrieved from: https://tspace.library.utoronto.ca/bitstream/1807/2733/ 2/19formsofinformal.pdf

Scott, K. W. (2004). Congruous autonomy: the 'pull' of personal commitment to extraordinary involvement in a pursuit. MPAEA Journal of Adult Education, 33(1), 7-18.

Villar, F. \& Celdrán, M. (2012). Generativity in Older Age: A Challenge for Universities of the Third Age (U3A). Educational Gerontology, 38(10), 666-677.

Weiss, R. S. (2005). Experience of retirement. Ithaca, NY: ILR Press

\section{Contact:}

Mgr. Salomeja Šatienè

Department of Administration and Education, Faculty of Social Sciences,

Klaipeda University of Applied Sciences,

Jaunystės g. 1, 91274, Klaipèda, Lithuania

E-mail: salomejasatiene@gmail.com 